\title{
Alain Roux \& Wang Xiaoling: Qu Qiubai (1899-1935), "Des mots de trop" (duoyu de hua). L'autobiographie d'un intellectuel engagé chinois.
} Paris-Louvain: Bibliothèque de l'INALCO ${ }^{\circ} 8$, Centre d'Études chinoises, 2005, 223 pp.

\section{Marie-Claire Bergère}

\section{OpenEdition}

\section{Journals}

Édition électronique

URL : http://journals.openedition.org/chinaperspectives/1051

DOI : 10.4000/chinaperspectives. 1051

ISSN : 1996-4617

\section{Éditeur}

Centre d'étude français sur la Chine contemporaine

Édition imprimée

Date de publication : 1 octobre 2006

ISSN : 2070-3449

\section{Référence électronique}

Marie-Claire Bergère, « Alain Roux \& Wang Xiaoling: Qu Qiubai (1899-1935), "Des mots de trop" (duoyu de hua). L'autobiographie d'un intellectuel engagé chinois. », China Perspectives [En ligne], 67 | september-october 2006, mis en ligne le 01 juin 2007, consulté le 24 septembre 2020. URL : http:// journals.openedition.org/chinaperspectives/1051; DOI : https://doi.org/10.4000/chinaperspectives. 1051

Ce document a été généré automatiquement le 24 septembre 2020

(c) All rights reserved 


\section{Alain Roux \& Wang Xiaoling: Qu Qiubai (1899-1935), "Des mots de trop" (duoyu de hua). L'autobiographie d'un intellectuel engagé chinois.}

Paris-Louvain: Bibliothèque de l'INALCO n 8 , Centre d'Études chinoises, 2005, 223 pp.

\section{Marie-Claire Bergère}

\section{NOTE DE L'ÉDITEUR}

Translated from the French original by Michael Black

$\mathrm{Qu}$ Qiubai was an unfortunate intellectual, whose tragic destiny illustrates the dilemmas faced, at the beginning of the twentieth century, by a whole generation of scholars, still steeped in the tradition of classical studies and scholarly leisure but already inclined towards modern forms of political commitment. The study of his career and of his thought is approached here through an analysis of his political testament entitled "Superfluous Words," which Qu Qiubai wrote in a Guomindang jail during the month which preceded his execution on June 18th 1935. The book is coauthored by Wang Xiaoling and Alain Roux. Wang Xiaoling carried out the checking of the chinese text, as well as its editing and translation. It is an elegant translation, through which the reader will be able to acquaint himself with the complex progression of this scholar who had broken with his class, and become one of the main theoreticians and leaders of the young Chinese Communist Party at the end of the 1920s. A solid complement of erudite footnotes, drawing on a wide-ranging chinese and Western bibliography, sheds light on the various stages of this journey. The Chinese 
text is reproduced in its entirety in the annex, in characters which are unfortunately very small.

2 This autobiography of $\mathrm{Qu}$ Qiubai is the most ambiguous of texts. Some see in it the political testament of an intellectual disillusioned by his political failures, others suspect that such a document was aimed at obtaining the pardon of its author, whose role in the Communist Party it seems to minimise, while still others consider that it is a meditation, with romantic or even Buddhist overtones, on the vanity of a wasted life which is nearing its end.

3 In two separate chapters, the co-authors detail their respective perceptions. In Chapter IV, entitled "Beyond the Text: the pains of commitment," Wang Xiaoling comments on (and most often paraphrases) the text, emphasising the historical conditions of its creation. To Wang, the author of "Superfluous Words," when he refers to his political commitment, "seems to want to show the reader that the Soviet model was not suited to the Chinese reality" and that "the tragic failure of his career" echoes that of the Communist Party as it strove, as the 1920s became the 1930s, to follow the line imposed by Stalin.

4 In Chapter I, "A Revolution Too Far", Alain Roux follows a more radical interpretation. Beneath the resigned acceptance of failure and the pain of a wasted life, he detects the persistence of real political fighting spirit. Far from signalling his renouncement, $\mathrm{Qu}$ Qiubai's reconversion to literature from 1931 on is seen as the beginning of the search for a new revolutionary path based on a rejection of all dogma, the exaltation of a literature for the masses and the corresponding revalorisation of the role of scholars. While this is a highly attractive suggestion, it may take the indications in the text a little too far.

5 Well presented, provided with an abundant Chinese and Western bibliography, a glossary of characters, an index of proper names, and a list of biographical notes, this book sheds as much light as possible on the text. The latter's appeal lies not only in its highly personal tone, which contrasts completely with the stereotyped formal language which was the rule in communist literature, but also in the mystery about the author's real intentions, as well as in the diverging interpretations to which it has given rise for over half a century. 